\title{
Effect of slag on the improvement of setting time and compressive strength of low reactive volcanic ash geopolymers synthetized at room temperature
}

\author{
Patrick N. Lemougna*1,2, A. Nzeukou ${ }^{1}$, B. Aziwo ${ }^{1}$, A.B. Tchamba ${ }^{1}$, Kai-tuo Wang ${ }^{3}$, U. \\ Chinje $\mathrm{Melo}^{4}$, Xue-min $\mathrm{Cui}^{3}$

\footnotetext{
${ }^{1}$ Local Materials Promotion Authority, MINRESI/ MIPROMALO, P.O. Box 2396 Yaounde, Cameroon ${ }^{2}$ Faculty of Technology, Fibre and Particle Engineering Unit, PO Box 4300, 90014 University of Oulu, Finland.

${ }^{3}$ School of Chemistry and Chemical Engineering and Guangxi Key Lab of Petrochemical Resource Processing and Process Intensification Technology, Guangxi University, Nanning, 530004, China ${ }^{4}$ Laboratory of Applied Inorganic Chemistry, Faculty of Science, University of Yaoundé I, P.O Box 812, Yaoundé, Cameroon
}

*Corresponding author: e-mail: Patrick.LemougnaNinla@oulu.fi , lemougna@yahoo.fr

\begin{abstract}
This paper presents an investigation on the effect of ground granulated blast furnace slag on the geopolymerization of low reactive volcanic ash. Volcanic ash was blended up to $50 \mathrm{wt} \%$ with slag at $10 \%$ intervals. The fresh geopolymer samples were cured at 25 and $60{ }^{\circ} \mathrm{C}$ for 3,7 and 28 days. XRD, FTIR, TG and SEM were used for phases analysis. The results outlined that only $10 \mathrm{wt} \%$ of slag was enough to reduce the initial setting time of the geopolymer from more than 7 days to couple of hours (6.7 hours). At $25^{\circ} \mathrm{C}$, the 28 days compressive strength increased with the addition of slag in the system until an optimum value of about 85 MPA. This strength development was suggested to arise from a synergetic formation of C-A-S-H $/ \mathrm{N}-\mathrm{A}-\mathrm{S}-\mathrm{H}$ gel. At $60{ }^{\circ} \mathrm{C}$, curing for periods longer than 7 days was not beneficial for strength development. These results are of interest for the valorization of low reactive volcanic ashes in the development of structural geopolymers, with related environmental and socioeconomic benefits.
\end{abstract}

Key words: Volcanic ash; GGBS; structural geopolymers; compressive strength; setting time 


\section{Introduction}

Ordinary Portland Cement (OPC) is a commonly used building material across the globe, the use of which was found to be second after water [1]. With the need for new infrastructures mainly in developing countries, the global production of cement has reached 4.6 billion tons in 2015 [2]. However, OPC is also a high energy intensive material, with an additional concern related to carbon dioxide $\left(\mathrm{CO}_{2}\right)$ released during its production, currently accounting for 5-8\% of global anthropogenic $\mathrm{CO}_{2}[3-5]$. These concerns have raised the pressure for the development of more environmentally friendly binders. Amongst these binders, geopolymers and alkali activated materials have emerged recently as a possible alternative with potential to partly replace Portland cement [6-16]. Alkali activated materials were defined as materials that encompass any binder system derived from the reaction of solid or dissolved alkali metal source with a solid silicate powder, while geopolymers are in many instances viewed as a subset of alkali activated materials where the binding phase is almost exclusively aluminosilicate with low calcium content such as calcined clay and low calcium fly ashes [17]. In this study, the term geopolymer will be used albeit slag with high Ca content was part of some compositions. Geopolymer chemistry involves the dissolution of aluminosilicate rich materials in the presence of an alkaline solution. The dissolved species made of aluminate and silicate units are then subjected to polycondensation reactions to form the geopolymer structure $[10,18,19]$. Amongst the potential natural aluminosilicates for geopolymer synthesis, volcanic ashes have been suggested to be one of the more efficient materials, because there is no need for calcination around $700{ }^{\circ} \mathrm{C}$ prior to their use, as in 
the case of kaolin in the production of metakaolin based geopolymer [20,21]. Volcanic ashes are pyroclastic materials abundantly found in the world, mainly in regions with past or present volcanic activity $[5,22]$. In comparison to clay mining, volcanic ash mining presents less environmental concerns because they are readily available, with no need for open quarrying method as for the case in mining operations of common clays [22]. It is also noteworthy that many volcanic ash deposits are unexploited meanwhile their valorization can be of environmental and economic benefit $[5,23,24]$; hence, the interest of their valorization in the development of structural geopolymers. However, the practical use of many volcanic ashes for geopolymer synthesis has been found to require some heat $\left(50-100{ }^{\circ} \mathrm{C}\right)$ necessary for hardening the geopolymer slurry in a reasonable time, and often for the development of acceptable strength $[20,21,24]$. This need is a drawback for their practical use in geopolymer synthesis because although this curing temperature is relatively low, the cost associated for a large-scale production will be significant. On the other hand, some aluminosilicate materials such as Ground Granulated Blast Furnace Slags (GGBS) were observed to be highly reactive for geopolymer synthesis, with potential to achieve a good reaction rate at temperatures as low as $0{ }^{\circ} \mathrm{C}$ [25]. GGBS is an industrial byproduct derived from pig iron. It has been observed to perform well in the development of cementitious materials $[4,12]$.

The present paper investigated the development of geopolymers from a synergetic use of a low reactive volcanic ash and GGBS, for potential structural applications. The effect of slag addition is assessed on the setting time and the development of strength at ambient temperature $\left(25^{\circ} \mathrm{C}\right)$. For comparative study, some specimens were also cured at $60{ }^{\circ} \mathrm{C}$. The effect of mixture composition on the 3,7 and 28-days compressive strength and the 
setting time was investigated. The products were also characterized by X-ray diffraction, scanning electron microscopy, thermogravimetry and Fourier transform infra-red spectroscopy.

\section{Experimental}

\subsection{Materials}

The primary raw materials used in this study were provided by local suppliers. The volcanic ash was from Petponoun in Foumbot (West region of Cameroon). The ash was obtained after grinding of the volcanic scoria. The alkaline activator used was sodium hydroxide, which was produced by Xilong Chemical Company. The GGBS used in this study was provided by the Chengde Group Company, Beihai Guangxi, P.R. China. The oxide composition of volcanic ash and slag determined by X-ray fluorescence, and their particle size determined with an OMEC Laser particle size distribution, are presented in Table 1and Figure 1 respectively.

Table 1: Chemical composition of the volcanic ash and slag

\begin{tabular}{ccccccccccc}
\hline & $\mathrm{Fe}_{2} \mathrm{O}_{3}$ & $\mathrm{Al}_{2} \mathrm{O}_{3}$ & $\mathrm{CaO}$ & $\mathrm{SiO}_{2}$ & $\mathrm{TiO}_{2}$ & $\mathrm{Na}_{2} \mathrm{O}$ & $\mathrm{MgO}$ & $\mathrm{SO}_{2}$ & $\mathrm{~K}_{2} \mathrm{O}$ & $\mathrm{MnO}$ \\
\hline $\begin{array}{c}\text { Volcanic } \\
\text { ash }\end{array}$ & 12 & 15.0 & 11 & 43 & 2.9 & 4.6 & 6.8 & - & 1.7 & 0.19 \\
\hline Slag & 0.63 & 15.32 & 37.15 & 34.21 & 0.80 & 0.39 & 9.34 & 1.82 & 0.41 & 0.59 \\
\hline
\end{tabular}




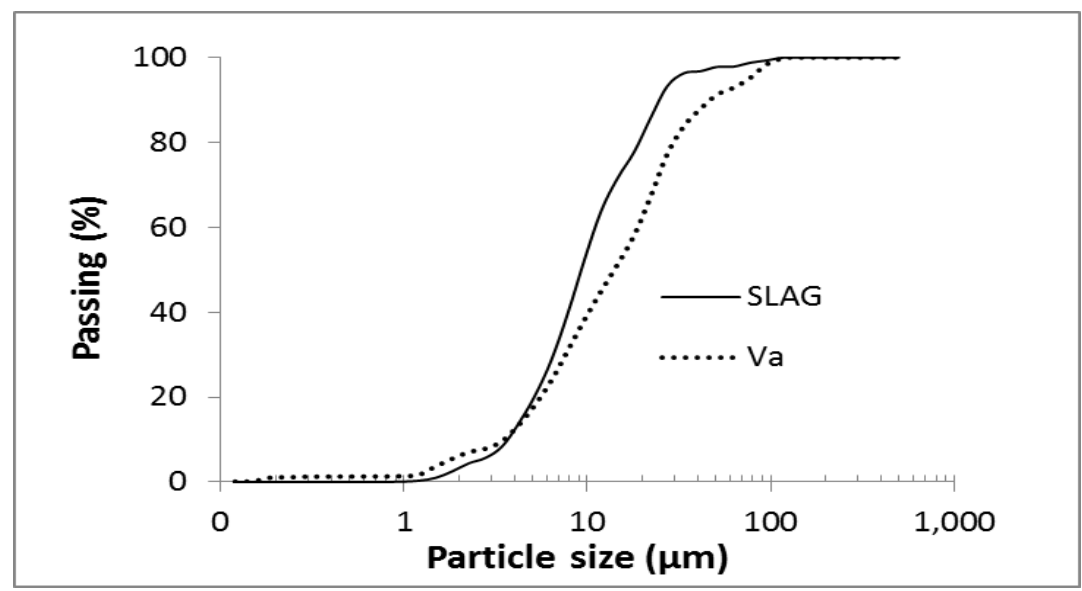

Figure 1: Particle size distribution of volcanic ash and slag

A non-corrosive alkaline activating solution with silica moduli $\left(\mathrm{R}=\mathrm{SiO}_{2} / \mathrm{Na}_{2} \mathrm{O}\right)$ of 1.6 was prepared by dissolving solid sodium hydroxide in a commercial sodium water glass with $\mathrm{R}=3.3$. In fact, sodium and potassium hydroxide solutions were classified as corrosive for skin when their modulus $\left(\mathrm{R}=\mathrm{SiO}_{2} / \mathrm{M}_{2} \mathrm{O}\right.$ with $\mathrm{M}=\mathrm{Na}$ or $\mathrm{K}$, $\mathrm{R}$ representing the molar ratio) is below 1.6 and irritating for the skin when this modulus is above 1.6 [26]. The prepared alkaline solution was sealed and stored for a minimum of $24 \mathrm{~h}$ prior to use.

\subsection{Specimens preparation}

The preparation of the fresh mixture was performed by mixing volcanic ash, GGBS and the alkaline solution of $\mathrm{R}=1.6$. The amount of volcanic ash substitution by slag was 0 to $50 \mathrm{wt} \%$ with $10 \mathrm{wt} \%$ interval. A composition made of $100 \mathrm{wt} \%$ slag was also prepared for reference. After preliminary investigation, the volcanic ash/water glass and 
slag/water glass weigh ratio were maintained to 3 and 2 respectively. The details on the mix proportioning are presented in Table 2 .

Table 2: Mixture proportioning

\begin{tabular}{cccccc}
\hline No & Volcanic ash (g) & Slag (g) & $\begin{array}{c}\text { Water glass } \\
\text { solution R=1.6 }\end{array}$ & $\begin{array}{c}\text { Na/Al molar } \\
\text { ratio }\end{array}$ & $\begin{array}{c}\text { Percentage of } \\
\text { Va } \\
\text { substitution }\end{array}$ \\
\hline 1 & 90 & 0 & 30 & 0.62 & 0 \\
\hline 2 & 81 & 9 & 31.5 & 0.65 & 10 \\
\hline 3 & 72 & 18 & 33 & 0.68 & 20 \\
\hline 4 & 63 & 27 & 34.5 & 0.71 & 30 \\
\hline 5 & 54 & 36 & 36 & 0.73 & 40 \\
\hline 6 & 45 & 45 & 37.5 & 0.76 & 50 \\
\hline 7 & 0 & 90 & 45 & 0.91 & 100 \\
\hline 8 & 90 & 0 & 45 & 0.92 & 0 \\
\hline
\end{tabular}

The mixing process was performed for about $10 \mathrm{~min}$, using an electric mixer at $750 \mathrm{rpm}$, until obtaining a homogenous paste. The samples were then casted in cubic alloy molds of $20 \times 20 \times 20 \mathrm{~mm}^{3}$, covered with a thin layer of plastic to facilitate the removal of the hardened paste upon curing. The alloy molds were vibrated on a vibration table for $2 \mathrm{~min}$ to remove air bubbles and sealed afterwards. The specimens were stored at $25{ }^{\circ} \mathrm{C}$ until the 3, 7 and 28-days compressive strength test. For comparative study, some specimens were also cured at $60{ }^{\circ} \mathrm{C}$ after their first day at $25^{\circ} \mathrm{C}$. The sketch of the experimental plan is presented in Figure 2. 


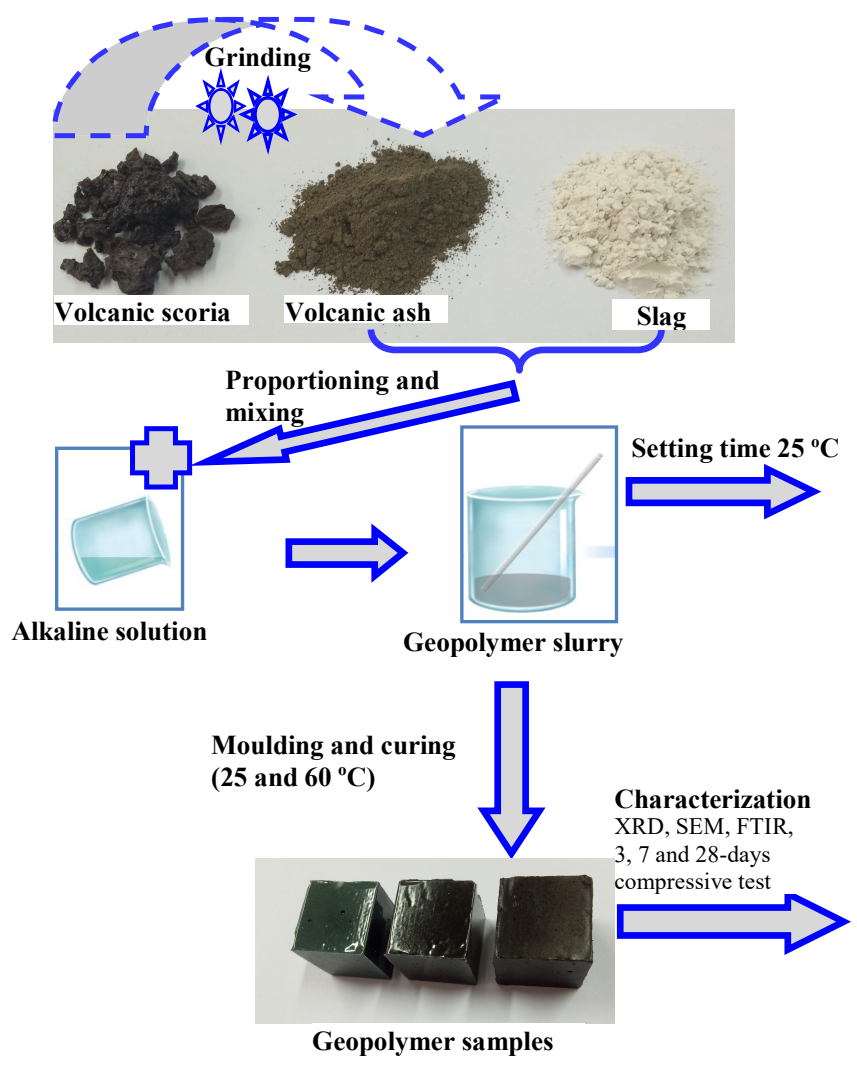

Figure 2: Sketch of the experimental plan

\subsection{Characterization method}

\subsubsection{XRD and FTIR analyses}

The starting volcanic ash and the prepared geopolymers were examined by X-ray diffraction using a Rigaku Mini Flex 600 instrument with Ni-filtered $\mathrm{Cu}(\mathrm{K} \alpha)$ radiation, a step size of $0.02^{\circ}$, operated at $40 \mathrm{kV}$ and $15 \mathrm{~mA}$, with a dwell time of 0.5 second and a $2 \theta$ range of 5 to $80^{\circ}$. The powdered samples were also pressed into $\mathrm{KBr}$ pellets for FTIR analysis using a Thermo Scientific FTIR spectrometer. 


\subsubsection{TG analysis}

The TG analysis of the starting materials and the prepared geopolymers was performed with a simultaneous STA409PC TG/DTA. The measurement was performed in air, at a constant heating rate of $5{ }^{\circ} \mathrm{C} / \mathrm{min}$, from room temperature to $1000^{\circ} \mathrm{C}$.

\subsubsection{SEM/EDX analysis}

Scanning Electron Microscopy (SEM) and Energy Dispersive X-ray Spectroscopy (EDX) were used to analyze the microstructure of the powdered slag and volcanic ash and the surfaces of the synthetized geopolymer specimens with an S-3400N device (Japan Hitachi Limited Company). Specimens were impregnated using absolute ethyl alcohol and polished with $\mathrm{SiC}$ paper, then coated with gold before measurement.

\subsubsection{Compressive strength testing}

The compressive strength test was performed on specimens using a DNS100 universal testing machine. The displacement rate was set to $0.5 \mathrm{~mm} / \mathrm{min}$. The test was performed on specimens cured at 3, 7 and 28 days. For each composition, at least three replicate samples were tested, and the average strength was regarded as the representative value. The error bar in Figure 9 indicates the standard deviation. 


\section{Results and discussions}

\subsection{XRD Analysis}

The results of XRD patterns are presented in Figure 3: volcanic ash (a), geopolymer from volcanic ash (b), geopolymer containing $90 \%$ volcanic ash and 10\% slag (c), geopolymer containing 70\% volcanic ash and 30\% slag (d), geopolymer containing 50\% volcanic ash and $50 \%$ slag (e), geopolymer from $100 \%$ slag (f) and pure slag (g). Slag was mainly amorphous, with some crystalline reflection around 28-30 degrees. Meanwhile, the crystalline phases found in volcanic ash were mainly alumimian augite, $\mathrm{Ca}(\mathrm{Mg}, \mathrm{Fe}$, $\mathrm{Al})(\mathrm{Si}, \mathrm{Al})_{2} \mathrm{O}_{6}$ (PDF no. 41-1483); sodium anorthite, $(\mathrm{Ca}, \mathrm{Na})(\mathrm{Al}, \mathrm{Si})_{2} \mathrm{Si}_{2} \mathrm{O}_{8}$ (PDF no. 20 $528)$ and ferroan forsterite, $(\mathrm{Mg}, \mathrm{Fe})_{2} \mathrm{SiO}_{4}$ (PDF no. 31-795).

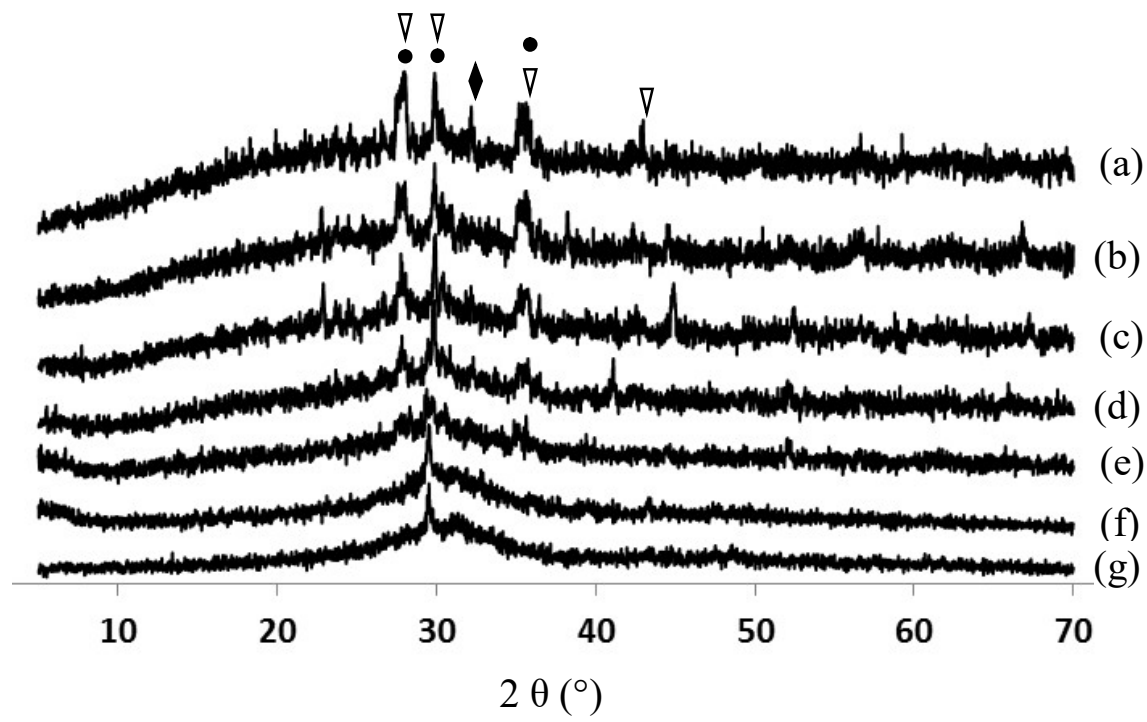

Key :

$\nabla=$ alumimian augite, $\mathrm{Ca}(\mathrm{Mg}, \mathrm{Fe}, \mathrm{Al})(\mathrm{Si}, \mathrm{Al})_{2} \mathrm{O}_{6}(\mathrm{PDF}$ no. 41-1483)

- = sodium anorthite, $(\mathrm{Ca}, \mathrm{Na})(\mathrm{Al}, \mathrm{Si})_{2} \mathrm{Si}_{2} \mathrm{O}_{8}(\mathrm{PDF}$ no. 20-528)

$\checkmark$ ferroan forsterite, $(\mathrm{Mg}, \mathrm{Fe})_{2} \mathrm{SiO}_{4}$ (PDF no. 31-795)

Figure 3: XRD patterns of slag, volcanic ash and prepared geopolymers 
It was observed after reaction of volcanic ash with sodium silicate solution that no new crystalline phases were formed. This indicates the amorphous character of the newly formed phase. Aside from that, the initial crystalline reflections of the ash were also present in the geopolymer, suggesting the difficulty of dissolving these crystalline phases in the alkaline conditions of the experiment. From the diffractograms (c, d and e), slag addition was found to mainly affect the XRD features of the geopolymer by reducing the intensity of the crystalline reflections. This was due to the relatively amorphous character of slag and the products resulting from alkali activation of volcanic ash/ slag system. Geopolymer resulting from slag (f) was mainly amorphous, with crystalline reflection of the starting slag around 28-30 degrees.

The amorphous fraction in volcanic ash and in other aluminosilicates were suggested to be more sensitive to geopolymer reaction, forming an amorphous geopolymer structure upon alkaline activation $[9,27,28]$. The presence of the starting crystalline phases in the prepared geopolymers is consistent with some previous studies on geopolymers from laterites [15] or volcanic ashes [20,27]. However, partial dissolution of the starting crystalline phases with possible participation in geopolymer reaction was also reported $[15,28]$.

\subsection{FTIR analysis}

The infrared spectra of the volcanic ash, geopolymers and slag are presented in Figure 4: volcanic ash (a), geopolymer from volcanic ash (b), geopolymer containing $90 \%$ volcanic 
ash and $10 \%$ slag (c), geopolymer containing $70 \%$ volcanic ash and $30 \%$ slag (d), geopolymer containing 50\% volcanic ash and 50\% slag (e), geopolymer from $100 \%$ slag (f) and slag (g).

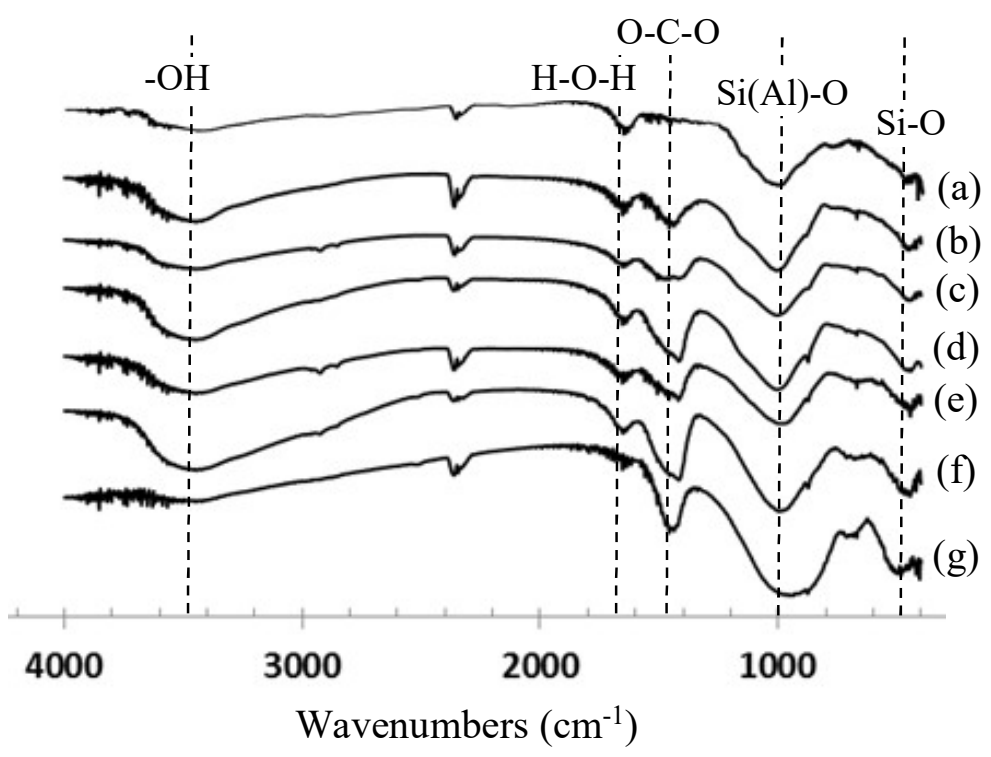

Figure 4: FTIR spectra of slag, volcanic ash and prepared geopolymers

The band around $460 \mathrm{~cm}^{-1}$ is ascribed to the bending vibration of $\mathrm{Si}-\mathrm{O}[29,30]$. The large band around $800-1200 \mathrm{~cm}^{-1}$ is ascribed to the stretching vibrations of $\mathrm{Si}(\mathrm{Al})-\mathrm{O}$ groups usually observed on the spectra of volcanic ash, geopolymers and slag $[9,13,30]$. This band is common in aluminosilicates material and was suggested to be sensitive to the content of structural $\mathrm{Si}$ and $\mathrm{Al}[10]$.

The bands around 1400 to $1500 \mathrm{~cm}^{-1}$ indicated the presence of O-C-O [30,31], usually ascribed to carbonation of geopolymer materials. The bands around 1640 and 3440 $\mathrm{cm}^{-1}$ are attributed to water and correspond to the characteristic regions of $\mathrm{O}-\mathrm{H}$ stretching and $\mathrm{H}-\mathrm{O}-\mathrm{H}$ bending in $\mathrm{H}_{2} \mathrm{O}[15,31]$. This water corresponds to either adsorbed or 
trapped in the structure cavities of the geopolymer [32]. It is noted that the peaks are intensified in geopolymer samples in comparison to the starting slag and volcanic ash, due to increased trapped water molecules in the geopolymer structure.

\subsection{Thermal gravimetry Analysis}

The TG analysis of the volcanic ash, slag and resulting geopolymers are presented in Figure 5.

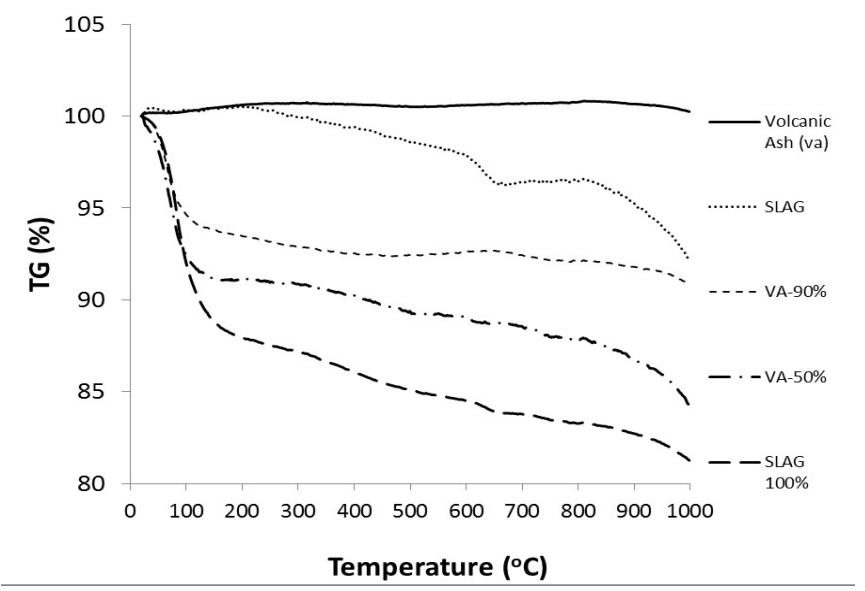

Figure 5: TG curves of slag, volcanic ash and referred geopolymers

Volcanic ash presented almost no mass loss until $1000^{\circ} \mathrm{C}$. Slag was stable until $250^{\circ} \mathrm{C}$, temperature at which some mass loss was initially observed. The total mass loss of slag was about $8 \%$ at $1000{ }^{\circ} \mathrm{C}$. At variance, inorganic polymers presented their major mass loss bellow $250{ }^{\circ} \mathrm{C}$, with the values of mass loss of about $7 \%, 10 \%$ and $12 \%$ at $250{ }^{\circ} \mathrm{C}$ for inorganic polymers made from 10, 50 and 100\% slag respectively. Hence, the substitution of volcanic ash by slag increased the mass loss below $250{ }^{\circ} \mathrm{C}$. This is 
ascribed to the formation of more geopolymer gel since the starting slag was almost stable until $250^{\circ} \mathrm{C}$. The mass loss below $250^{\circ} \mathrm{C}$ is then attributed to the reaction product of alkali activated slag, mainly CAS-H gel, agreeing with reported studies on alkali activated slag [8], as well as alkali activated volcanic ash [27], where the mass loss around $200{ }^{\circ} \mathrm{C}$ was attributed to the formation of CAS-H gel. At $1000{ }^{\circ} \mathrm{C}$, the total mass loss of the inorganic polymer containing 10,50 and $100 \mathrm{wt} \%$ slag was about 10,16 and $19 \%$ respectively. These features of main mass loss bellow $300{ }^{\circ} \mathrm{C}$ are also like those observed on metakaolin based geopolymer $[33,34]$.

\subsection{Microstructural characterization}

The SEM images of volcanic ash and slag powder are presented in Figure 6. Slag particles (Figure 6a) were globally smaller than volcanic ash particles (Figure 6b), in agreement with their particle size information in Figure 1. Volcanic ash particles were mainly composed of $\mathrm{Al}, \mathrm{Si}$ and $\mathrm{Ca}$ elements, similarly to slag particles. However, the latter contained more $\mathrm{Ca}$ element. 


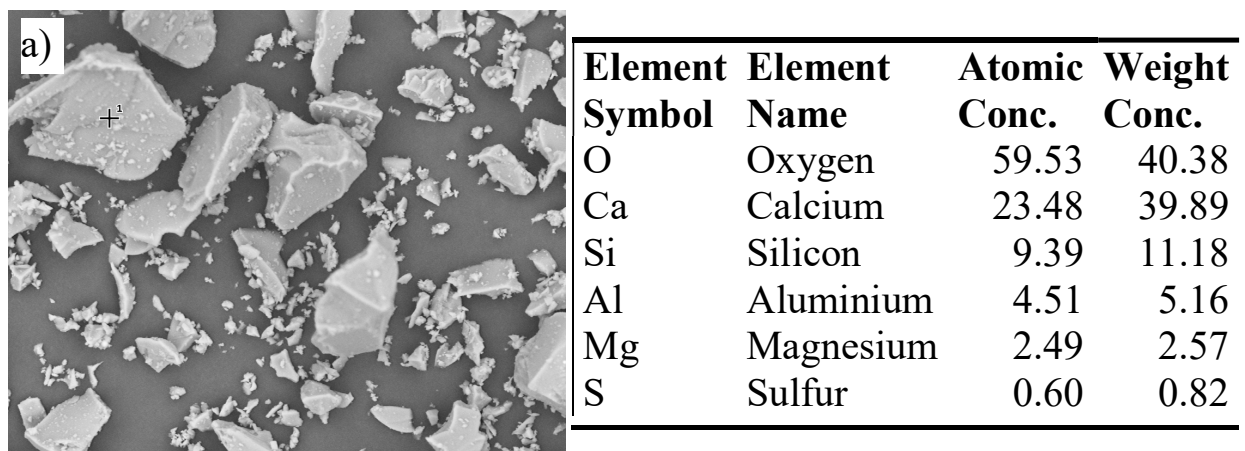

\begin{tabular}{|c|c|c|c|}
\hline Element & Element & Atomic & Weight \\
\hline Symbol & Name & Conc. & Conc. \\
\hline $\mathrm{O}$ & Oxygen & 59.53 & 40.38 \\
\hline $\mathrm{Ca}$ & Calcium & 23.48 & 39.89 \\
\hline $\mathrm{Si}$ & Silicon & 9.39 & 11.18 \\
\hline $\mathrm{Al}$ & Aluminium & 4.51 & 5.1 \\
\hline $\mathrm{Mg}$ & Magnesium & 2.49 & 2.57 \\
\hline$\sigma$ & Sulfur & 0.60 & 0.82 \\
\hline
\end{tabular}

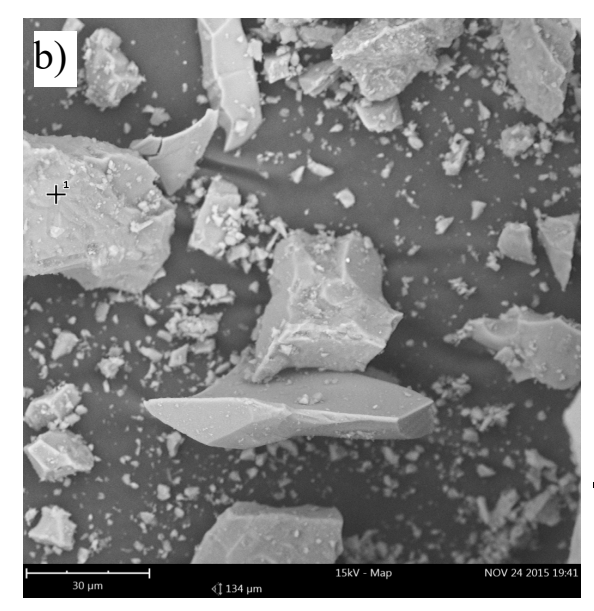

\begin{tabular}{|c|c|c|c|}
\hline$\overline{\text { Eler }}$ & Ele & Atomic & Weight \\
\hline Symbc & Name & Conc. & Conc. \\
\hline $\mathrm{O}$ & Oxygen & 69.44 & 54.87 \\
\hline $\mathrm{Si}$ & Silicon & 13.06 & 18.12 \\
\hline $\mathrm{Al}$ & Aluminium & 8.81 & 11.74 \\
\hline $\mathrm{Na}$ & Sod & 05 & 3.46 \\
\hline $\mathrm{Ca}$ & Calc & 61 & 5.16 \\
\hline $\mathrm{Mg}$ & Magn & .43 & 1.72 \\
\hline $\mathrm{Fe}$ & Iron & 1.03 & 2.85 \\
\hline
\end{tabular}

Figure 6: SEM images of slag (a) and volcanic ash (b)

The SEM/EDS of composition made of $10 \%$ slag (a) and 50\% slag (b) revealed a relatively homogenous distribution of $\mathrm{Si}, \mathrm{Al}$ and $\mathrm{Na}$ element, ascribed to a good formation of inorganic polymer (Figure 7). However, from the analysis of the element maps, an incomplete dissolution of $\mathrm{Mg}$ rich particles is observed. Considering the ash mineral composition, the $\mathrm{Mg}$ rich particles are ascribed to ferroan forsterite. 


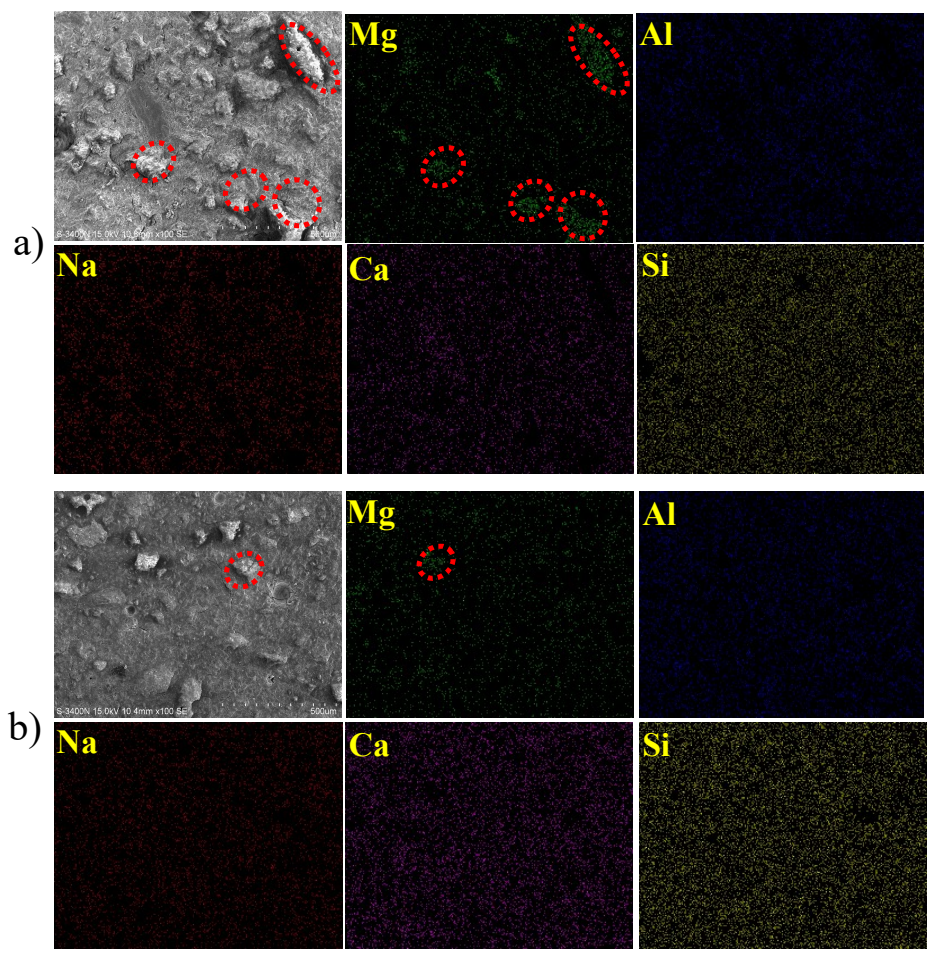

Figure 7: SEM/EDS of composition made of $10 \%$ slag (a) and $50 \%$ slag (b)

The hard dissolution of forsterite ferroan bearing phase in the ash is in agreement with reported studies on volcanic ash based geopolymers [35]. The homogenously good distribution of $\mathrm{Ca}, \mathrm{Al}$ and $\mathrm{Si}$ elements is ascribed to the formation of CASH gel. The CASH gel of alkali activated materials was suggested to be highly stable as C-S-H gel of OPC systems in case of limited structural disorder and proper charge balancing during their synthesis [6]. Beside from that, an appropriate mixture of Ca rich aluminosilicate such as slag and Ca poor material such volcanic ash was suggested to be of potential benefit for the development of mechanical properties due to the formation of a synergetic mixture of CASH and NASH gel [36]. This is likely to be the case in the 
present study, considering the positive effect of slag addition in the compressive strength presented in the next section.

\subsection{Setting time and compressive strength}

The setting times of the geopolymer compositions containing $10 \%, 30 \%, 50 \%$ and 100 wt $\%$ slag are presented in Figure 8.

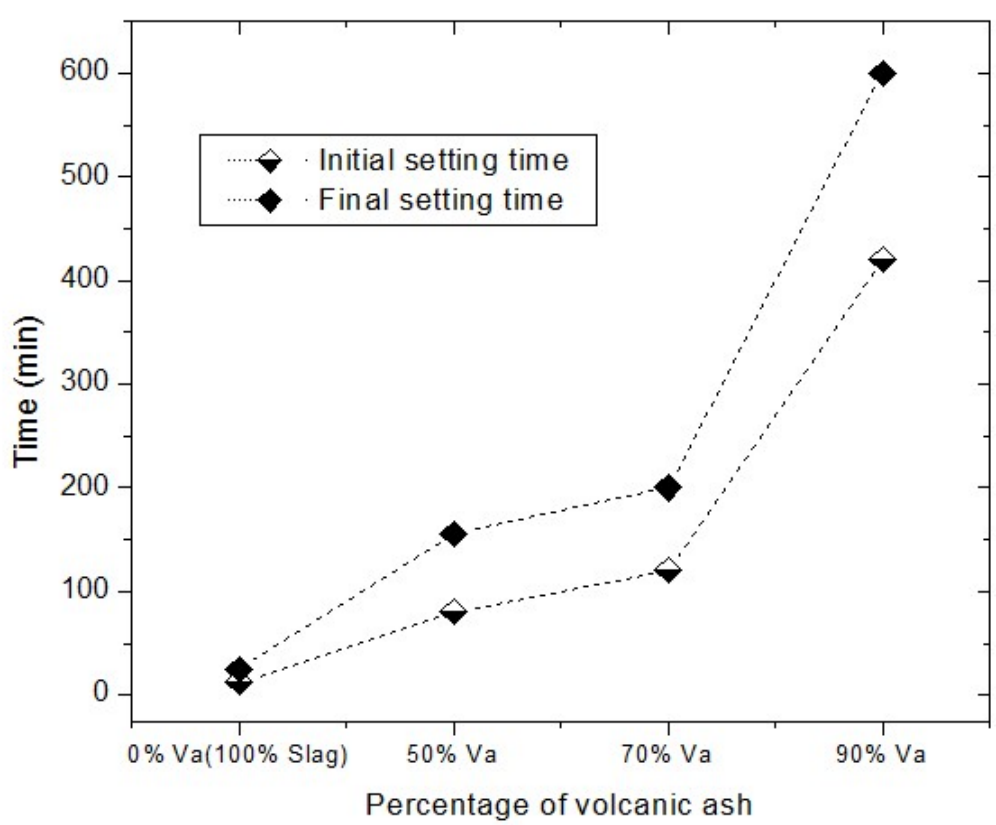

Figure 8: Initial and final setting time of referred compositions

It is worth pointing out that the initial setting time of the composition made of $100 \mathrm{wt} \%$ volcanic ash at $25^{\circ} \mathrm{C}$ was above 7 days, hence about 25 times the value of 400 minutes (about 6.7 hours) of the initial setting time of the composition obtained by substituting 10 $\mathrm{wt} \%$ volcanic ash by slag (Figure 8 ). When the amount of volcanic ash substitution by 
slag increased from $10 \mathrm{wt} \%$ to $50 \mathrm{wt} \%$, the setting time was further reduced, but now in a lesser extent. The setting time is an important parameter for binding materials. It should be reasonable to allow suitable time for mixing and shaping operation. However, when the setting time is more than couple of hours and days, the production efficiency is negatively affected. The use of the current volcanic ash to produce geopolymers for potential building application at $25{ }^{\circ} \mathrm{C}$ is highly hampered by the very long setting time and a low compressive strength. However, only $10 \mathrm{wt} \%$ substitution of volcanic ash by slag was enough to reduce the initial setting time to a reasonable time. Slag was found to have a short initial setting time (less than $15 \mathrm{~min}$ ).

Hence, volcanic ash can also be used to extent the setting time of slag based geopolymer to a reasonable value.

The 3, 7 and 28-days compressive strength of geopolymers from the different compositions are presented in Figure 9. 

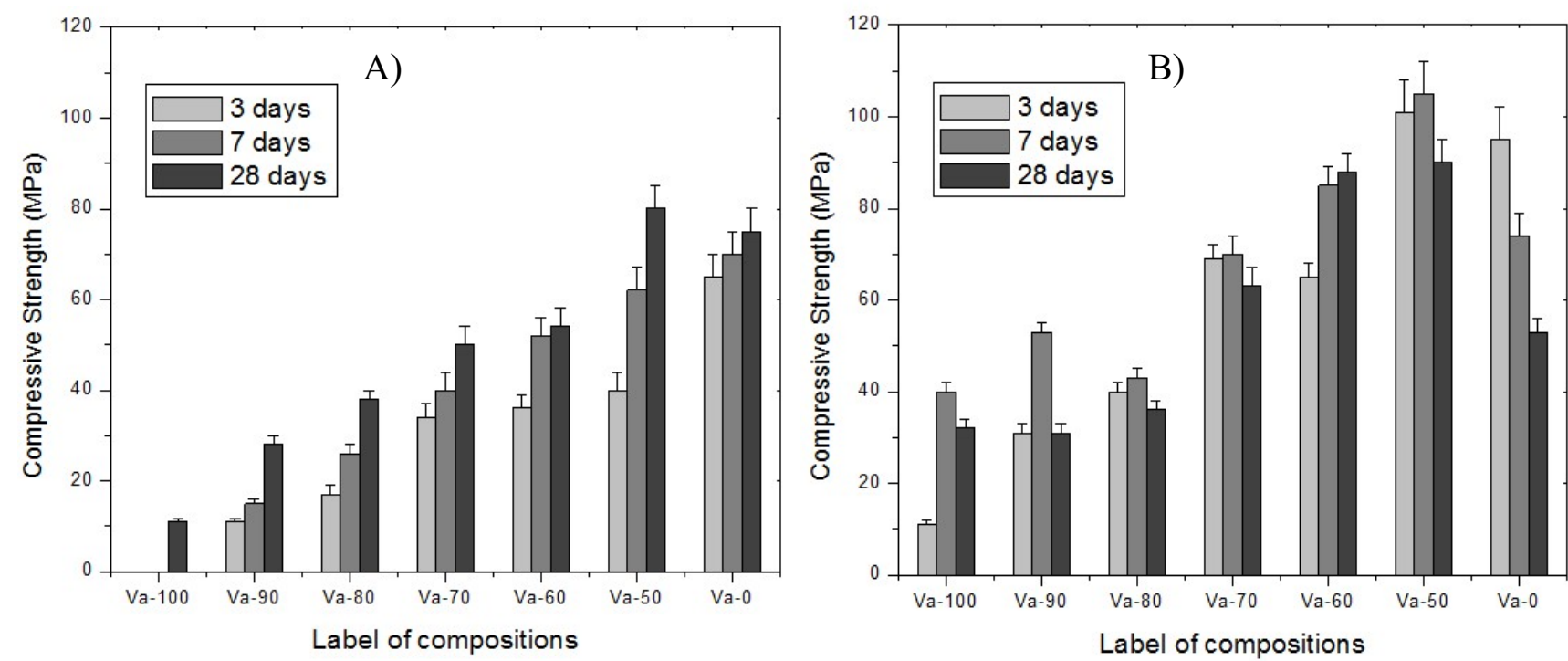

Figure 9: 3, 7 and 28-days compressive strength of referred compositions cured at $25{ }^{\circ} \mathrm{C}$ (A) and $60^{\circ} \mathrm{C}(\mathrm{B})$

At $25^{\circ} \mathrm{C}$ (Figure $9 \mathrm{~A}$ ), it was observed that the composition made of $100 \mathrm{wt} \%$ volcanic ash was still soft and deformable by hand pressure after 7 days; therefore, the compressive strength test was only performed at 28 days for this composition. The compressive strength was found to increase with slag addition in the system until an optimum value of about $85 \mathrm{MPa}$ after 28 days curing for specimens prepared with 50 $\mathrm{wt} \%$ slag and $50 \mathrm{wt} \%$ volcanic ash. The composition made of $100 \mathrm{wt} \%$ slag presented a compressive strength of about $80 \mathrm{MPA}$ at 28 day curing at $25^{\circ} \mathrm{C}$. However, the 3 and 7 days compressive strength of the composition prepared with $100 \mathrm{wt} \%$ slag were about 70 and $75 \mathrm{MPa}$ respectively, above the 3 and 7 days compressive strength of compositions prepared with $50 \mathrm{wt} \%$ slag and $50 \mathrm{wt} \%$ volcanic ash (about 45 and $60 \mathrm{MPa}$ respectively). At $25^{\circ} \mathrm{C}$, the compressive strength was found to globally increase with the increase of curing time from 3 to 28 days for all the compositions. This was at variance with the 
results of samples cured at $60{ }^{\circ} \mathrm{C}$, where the optimum curing time was 7 days for compositions containing volcanic ash and 3 days for the composition containing only slag (Figure 9 B). Reasons for the decrease of strength with curing time at $60{ }^{\circ} \mathrm{C}$ are geopolymer gel dehydration and possible micro cracks formation resulting from the dehydration process as the curing time went on. Hence, at $60{ }^{\circ} \mathrm{C}$ or higher temperatures, there is no need to extend the curing time beyond 3 days for samples containing only slag and 7 days for samples containing both slag and volcanic ash especially when the curing environment is not saturated in water. These results are consistent with some reported studies on alkali activated materials. Indeed, for geopolymer or alkali activated systems, an increase of the mechanical properties with the curing temperatures is usually observed until a threshold temperature above which there is no strength-gaining [9,37,38]. This threshold temperature was found in some case around $60-70^{\circ} \mathrm{C}[38,39]$ for some metakaolin based geopolymers, $30-40^{\circ} \mathrm{C}$ for fly ash geopolymer-Portland cementitious system [37], $60-90^{\circ} \mathrm{C}$ for low calcium fly ash and volcanic ashes based geopolymers $[9,20,37]$ and $40^{\circ} \mathrm{C}$ for slag based alkali activated materials [3]. Beyond this temperature, the time for a better dissolution of aluminosilicates becomes insufficient due to a rapid setting of the geopolymer gel formed at the surface of the undissolved particles $[3,40]$. High temperature curing may also reduce strength due to microcracks formation induced from rapid loss of water when the curing environment is not sutured in water [40]. The positive effect of slag substitution by volcanic ash observed in this study agrees with a reported study carried out by Robayo-Salazar et al. [41] on a Colombian volcanic ash. However, Onoue and Bier [42] observed slag replacement ratio to have little influence on flexural and compressive strengths on geopolymers made from a German volcanic ash. 
These divergences are probably linked to the divergence in chemical and mineralogical composition of volcanic ash from diverse sources.

The compressive test and setting time results obtained in the present study suggest that some poorly reactive volcanic ashes could be mixed with ground granulated blast furnace slag or other suitable high calcium rich aluminosilicates to produce structural geopolymers with interesting properties at ambient temperature (around $25^{\circ} \mathrm{C}$ ). Indeed, moderate addition ( $8-24 \mathrm{wt} \%)$ of calcium aluminate cement was also found to be beneficial for geopolymer reactions resulting in higher compressive strength [32]. The most important quality index of building materials such as building bricks is their compressive strength [43]. The optimum value of compressive strength obtained in this study $(85 \mathrm{MPa})$ is above the one obtained in many geopolymers prepared from metakaolin or volcanic ashes $[21,24,28,29]$. These values are also above the minimum requirement for most building materials, including paving brick subjected to light traffic, requesting minimum compressive strength of 17.2-20.7 MPa [43]. The overall results are of great interest for the valorization of volcanic ash for building applications, with related environmental and societal benefits. 


\section{Conclusions}

Geopolymers with very good mechanical properties were successfully prepared from a low reactive volcanic ash and slag at $25^{\circ} \mathrm{C}$. Slag addition was found to have a good effect on both setting time and compressive strength. The development of strength was ascribed to a synergetic formation of C-A-S-H / N-A-S-H gel. Only $10 \%$ of slag was enough to reduce the setting time of the geopolymer from more than 7 days to a couple of hours (6.7 hours) at $25{ }^{\circ} \mathrm{C}$. The compressive strength was found to globally increase with the increase in curing time from 3 to 28 days for all the compositions cured at $25^{\circ} \mathrm{C}$, until an optimum value of about $85 \mathrm{MPA}$. At $60{ }^{\circ} \mathrm{C}$, the optimum curing time was 7 days for compositions containing volcanic ashes and 3 days for the composition containing only slag. The overall results are very significant for the valorization of low reactive volcanic ashes in the development of structural geopolymers, with related environmental and societal benefits.

\section{Acknowledgments}

This work was supported by the Chinese Natural Science Fund (grant: 51262002, 21566006 and 51561135012). PLN is also acknowledging the Postdoctoral Project from the Fibre and Particle Engineering Unit, University of Oulu, Finland. 


\section{References}

[1] G. Habert, J.B. d'Espinose de Lacaillerie, N. Roussel, An environmental evaluation of geopolymer based concrete production: reviewing current research trends, Journal of Cleaner Production. 19 (2011) 1229-1238. doi:10.1016/j.jclepro.2011.03.012.

[2] K.L. Scrivener, V.M. John, E.M. Gartner, Eco-efficient cements: Potential, economically viable solutions for a low $\mathrm{CO} 2$, cement based materials industry, UNEP (UN Environment Program). (2016).

[3] P.N. Lemougna, K. Wang, Q. Tang, X. Cui, Study on the development of inorganic polymers from red mud and slag system: Application in mortar and lightweight materials, Construction and Building Materials. 156 (2017) 486-495. doi:10.1016/j.conbuildmat.2017.09.015.

[4] T. Luukkonen, Z. Abdollahnejad, J. Yliniemi, P. Kinnunen, M. Illikainen, One-part alkali-activated materials: A review, Cem. Concr. Res. 103 (2018) 21-23. doi:10.1016/j.cemconres.2017.10.001.

[5] P.N. Lemougna, K. Wang, Q. Tang, A.N. Nzeukou, N. Billong, U.C. Melo, X. Cui, Review on the use of volcanic ashes for engineering applications, Resources, Conservation and Recycling. 137 (2018) 177-190.

doi:10.1016/j.resconrec.2018.05.031.

[6] V.O. Özçelik, C.E. White, Nanoscale Charge Balancing Mechanism in Alkali Substituted Calcium-Silicate-Hydrate Gels, The Journal of Physical Chemistry Letters. 7 (2016) 5266-5272. doi:10.1021/acs.jpclett.6b02233.

[7] T. Luukkonen, Z. Abdollahnejad, J. Yliniemi, P. Kinnunen, M. Illikainen, Comparison of alkali and silica sources in one-part alkali-activated blast furnace slag mortar, Journal of Cleaner Production. 187 (2018) 171-179.

[8] E. Adesanya, K. Ohenoja, T. Luukkonen, P. Kinnunen, M. Illikainen, One-part geopolymer cement from slag and pretreated paper sludge, Journal of Cleaner Production. 185 (2018) 168-175. doi:10.1016/j.jclepro.2018.03.007.

[9] P.N. Lemougna, K. Wang, Q. Tang, U.C. Melo, X. Cui, Recent developments on inorganic polymers synthesis and applications, Ceramics International. 42 (2016) 15142-15159. doi:10.1016/j.ceramint.2016.07.027.

[10] J. Davidovits, Geopolymer chemistry and applications, Geopolymer Institute, 2008.

[11] A. Peys, H. Rahier, Y. Pontikes, Potassium-rich biomass ashes as activators in metakaolin-based inorganic polymers, Applied Clay Science. 119 (2016) 401-409. doi:10.1016/j.clay.2015.11.003.

[12] J.S.J. Van Deventer, J.L. Provis, P. Duxson, Technical and commercial progress in the adoption of geopolymer cement, Minerals Engineering. 29 (2012) 89-104. doi:10.1016/j.mineng.2011.09.009.

[13] M.F. Zawrah, R.S. Farag, M.H. Kohail, Improvement of physical and mechanical properties of geopolymer through addition of zircon, Materials Chemistry and Physics. 217 (2018) 90-97. doi:10.1016/j.matchemphys.2018.06.024.

[14] D.E. Tchinda Mabah, H.K. Tchakouté, C.H. Rüscher, E. Kamseu, A. Elimbi, C. Leonelli, Design of low cost semi-crystalline calcium silicate from biomass for the improvement of the mechanical and microstructural properties of metakaolin-based 
geopolymer cements, Materials Chemistry and Physics. 223 (2019) 98-108. doi:10.1016/j.matchemphys.2018.10.061.

[15] C.R. Kaze, J.N.Y. Djobo, A. Nana, H.K. Tchakoute, E. Kamseu, U.C. Melo, C. Leonelli, H. Rahier, Effect of silicate modulus on the setting, mechanical strength and microstructure of iron-rich aluminosilicate (laterite) based-geopolymer cured at room temperature, Ceramics International. 44 (2018) 21442-21450. doi:10.1016/j.ceramint.2018.08.205.

[16] S. Pilehvar, V.D. Cao, A.M. Szczotok, M. Carmona, L. Valentini, M. Lanzón, R. Pamies, A.-L. Kjøniksen, Physical and mechanical properties of fly ash and slag geopolymer concrete containing different types of micro-encapsulated phase change materials, Construction and Building Materials. 173 (2018) 28-39. doi:10.1016/j.conbuildmat.2018.04.016.

[17] J.L. Provis, J.S.J. van Deventer, Alkali Activated Materials: State-of-the-art report, RILEM TC 224-AAM, Springer Dordrecht, 2014. https://www.rilem.net/docs/2014090109_star-224-aam_final-draft_full.pdf.

[18] Q. Tang, G. Xue, S. Yang, K. Wang, X. Cui, Study on the preparation of a freesintered inorganic polymer-based proppant using the suspensions solidification method, Journal of Cleaner Production. 148 (2017) 276-282. doi:10.1016/j.jclepro.2017.02.001.

[19] W. Li, P.N. Lemougna, K. Wang, Y. He, Z. Tong, X. Cui, Effect of vacuum dehydration on gel structure and properties of metakaolin-based geopolymers, Ceramics International. 43 (2017) 14340-14346. doi:10.1016/j.ceramint.2017.07.190.

[20] P.N. Lemougna, K.J.D. MacKenzie, U.F.C. Melo, Synthesis and thermal properties of inorganic polymers (geopolymers) for structural and refractory applications from volcanic ash, Ceramics International. 37 (2011) 3011-3018. doi:10.1016/j.ceramint.2011.05.002.

[21] H. Takeda, S. Hashimoto, H. Kanie, S. Honda, Y. Iwamoto, Fabrication and characterization of hardened bodies from Japanese volcanic ash using geopolymerization, Ceramics International. 40 (2014) 4071-4076. doi:10.1016/j.ceramint.2013.08.061.

[22] E. Kamseu, D.N. Boccaccini, U.C. Melo, A. Rizzuti, N. Billong, P. Miselli, Volcanic ash as alternative raw materials for traditional vitrified ceramic products AU - Leonelli, C., Advances in Applied Ceramics. 106 (2007) 135-141. doi:10.1179/174367607X159329.

[23] G. Cai, T. Noguchi, H. Degée, J. Zhao, R. Kitagaki, Volcano-related materials in concretes: a comprehensive review, Environmental Science and Pollution Research. 23 (2016) 7220-7243. doi:10.1007/s11356-016-6161-z.

[24] J.N.Y. Djobo, A. Elimbi, H.K. Tchakouté, S. Kumar, Volcanic ash-based geopolymer cements/concretes: the current state of the art and perspectives, Environmental Science and Pollution Research. 24 (2017) 4433-4446. doi:10.1007/s11356-016-8230-8.

[25] K. Wang, P.N. Lemougna, Q. Tang, W. Li, Y. He, X. Cui, Low temperature depolymerization and polycondensation of a slag-based inorganic polymer, Ceramics International. 43 (2017) 9067-9076. doi:10.1016/j.ceramint.2017.04.052. 
[26] C E E S, SOLUBLE SILICATES, Chemical, toxicological, ecological and legal aspects of production, transport, handling and application, (2014). https://www.cees-silicates.org/images/Publications/solsil_broch_1411.pdf.

[27] B.I. Djon Li Ndjock, A. Elimbi, M. Cyr, Rational utilization of volcanic ashes based on factors affecting their alkaline activation, Journal of Non-Crystalline Solids. 463 (2017) 31-39. doi:10.1016/j.jnoncrysol.2017.02.024.

[28] P.N. Lemougna, U.F. Chinje Melo, M.-P. Delplancke, H. Rahier, Influence of the chemical and mineralogical composition on the reactivity of volcanic ashes during alkali activation, Ceramics International. 40 (2014) 811-820. doi:10.1016/j.ceramint.2013.06.072.

[29] H.K. Tchakouté, C.H. Rüscher, E. Kamseu, J.N.Y. Djobo, C. Leonelli, The influence of gibbsite in kaolin and the formation of berlinite on the properties of metakaolin-phosphate-based geopolymer cements, Materials Chemistry and Physics. 199 (2017) 280-288. doi:10.1016/j.matchemphys.2017.07.020.

[30] M. Torres-Carrasco, C. Rodríguez-Puertas, M. del M. Alonso, F. Puertas, Alkali activated slag cements using waste glass as alternative activators. Rheological behaviour, Boletín de La Sociedad Española de Cerámica y Vidrio. 54 (2015) 4557. doi:10.1016/j.bsecv.2015.03.004.

[31] P.N. Lemougna, K. Wang, Q. Tang, X. Cui, Synthesis and characterization of low temperature $\left(<800^{\circ} \mathrm{C}\right)$ ceramics from red mud geopolymer precursor, Construction and Building Materials. 131 (2017) 564-573. doi:10.1016/j.conbuildmat.2016.11.108.

[32] M. Vafaei, A. Allahverdi, Influence of calcium aluminate cement on geopolymerization of natural pozzolan, Construction and Building Materials. 114 (2016) 290-296. doi:10.1016/j.conbuildmat.2016.03.204.

[33] J.L. Bell, P.E. Driemeyer, W.M. Kriven, Formation of Ceramics from MetakaolinBased Geopolymers. Part II: K-Based Geopolymer, Journal of the American Ceramic Society. 92 (2009) 607-615. doi:10.1111/j.1551-2916.2008.02922.x.

[34] H. Rahier, B. Van Mele, J. Wastiels, Low-temperature synthesized aluminosilicate glasses, Journal of Materials Science. 31 (1996) 80-85. doi:10.1007/BF00355129.

[35] P.N. Lemougna, K.J.D. MacKenzie, G.N.L. Jameson, H. Rahier, U.F.C. Melo, The role of iron in the formation of inorganic polymers (geopolymers) from volcanic ash: a 57Fe Mössbauer spectroscopy study, J Mater Sci. 48 (2013) 5280-5286. doi:10.1007/s10853-013-7319-4.

[36] J.L. Provis, S.A. Bernal, Geopolymers and Related Alkali-Activated Materials, Annual Review of Materials Research. 44 (2014) 299-327. doi:10.1146/annurevmatsci-070813-113515.

[37] T. Suwan, M. Fan, N. Braimah, Micro-mechanisms and compressive strength of Geopolymer-Portland cementitious system under various curing temperatures, Materials Chemistry and Physics. 180 (2016) 219-225. doi:10.1016/j.matchemphys.2016.05.069.

[38] F.G.M. Aredes, T.M.B. Campos, J.P.B. Machado, K.K. Sakane, G.P. Thim, D.D. Brunelli, Effect of cure temperature on the formation of metakaolinite-based geopolymer, Ceramics International. 41 (2015) 7302-7311. doi:10.1016/j.ceramint.2015.02.022. 
[39] B. Mo, H. Zhu, X. Cui, Y. He, S. Gong, Effect of curing temperature on geopolymerization of metakaolin-based geopolymers, Applied Clay Science. 99 (2014) 144-148. doi:10.1016/j.clay.2014.06.024.

[40] Y.-M. Liew, C.-Y. Heah, A.B. Mohd Mustafa, H. Kamarudin, Structure and properties of clay-based geopolymer cements: A review, Progress in Materials Science. 83 (2016) 595-629. doi:10.1016/j.pmatsci.2016.08.002.

[41] R.A. Robayo-Salazar, M. de Gutiérrez, F. Puertas, Study of synergy between a natural volcanic pozzolan and a granulated blast furnace slag in the production of geopolymeric pastes and mortars, Construction and Building Materials. 157 (2017) 151-160. doi:10.1016/j.conbuildmat.2017.09.092.

[42] K. Onoue, T.A. Bier, Optimization of alkali-activated mortar utilizing ground granulated blast-furnace slag and natural pozzolan from Germany with the dynamic approach of the Taguchi method, Construction and Building Materials. 144 (2017) 357-372. doi:10.1016/j.conbuildmat.2017.03.189.

[43] R. Taurino, A. Karamanov, R. Rosa, E. Karamanova, L. Barbieri, S. AtanasovaVladimirova, G. Avdeev, C. Leonelli, New ceramic materials from MSWI bottom ash obtained by an innovative microwave-assisted sintering process, Journal of the European Ceramic Society. 37 (2017) 323-331. doi:10.1016/j.jeurceramsoc.2016.08.011. 